\title{
POR QUE ESCREVO
}

\author{
Paulo Henriques Brito
}

Quando perguntaram a George Orwell por que ele escrevia, a primeira resposta que ele deu foi esta: escrevo por vaidade, para deixar uma marca, para que as pessoas lembrem de mim. Orwell certamente tinha razão. Essa é uma motivação de todos os escritores, mesmo daqueles que engavetam todos os seus escritos. No meu caso, o desejo de reconhecimento, pelos meus contemporâneos e por uma imaginada posteridade, é de fato é um dos motivos que me levam a escrever, mas eu hesitaria em dizer que é o primeiro em importância, e não tenho dúvida de que não foi o primeiro em termos cronológicos.

Talvez valha a pena começar mencionando alguns motivos que não se incluem entre os fatores que me levam a escrever. Não escrevo por dinheiro - ou, melhor dizendo, escrevo por dinheiro, sim, mas o que escrevo por dinheiro é uma modalidade muito específica de escrita - a tradução literária, que não é meu tema aqui. Os poemas (e eventuais contos) que escrevo, ainda que por vezes me proporcionem algum dinheiro, por direitos autorais ou prêmios literários, não têm um peso importante na minha renda. Também não escrevo por necessidade de expressão - uma resposta que sem dúvida me ocorreria se me fizessem essa pergunta quando eu tinha meus dezoito anos de idade; como já tive oportunidade de relatar uma vez, ${ }^{1}$ o que naquele tempo me parecia 
necessidade de exprimir sentimentos pré-existentes passei a ver, depois de adulto, como uma necessidade de dar forma a sentimentos no próprio ato de escrever sobre eles, de modo que o que eu via como expressão de uma personalidade hoje me parece mais ter sido um processo de construção de uma personalidade. Seja como for, há pelo menos um quarto de século esse não é mais um dos motores da minha escrita. Também não escrevo movido pela ideia de ajudar a mudar o mundo, a reparar injustiças e promover causas meritórias. Nada contra quem põe sua escrita a serviço de uma missão ou uma ideologia; coisas muito boas (e também muito ruins) foram produzidas com esse intuito; mas não é isso que me leva a escrever.

Talvez a motivação mais forte de todas seja também uma negativa: a minha absoluta falta de talento musical. Nenhuma arte é tão importante para mim quanto a música; nada me afeta tanto quanto a música. E a constatação de não ter o mínimo de talento necessário para sequer ser um músico medíocre, um músico amador medíocre, me levou a tentar a sorte na arte que me interessava mais depois da música, a literatura. Aqui, mais uma vez, as negativas entram em jogo. Pois, por mais que eu ame a poesia, por maior que tenha sido o impacto que teve sobre a minha vida a leitura de alguns poetas, principalmente os que li na puberdade e na adolescência - primeiro Shakespeare, Dickinson e Whitman, depois Pessoa, sobretudo Pessoa, o poeta que mais li e reli e imitei e emulei, depois Drummond, Bandeira, e por fim João Cabral e Wallace Stevens - nenhum escritor foi tão importante para mim quanto um prosador, e um prosador que escreve numa língua que não sei ler: Kafka. A leitura de Kafka, no momento em que o descobri, por volta dos dezessete ou dezoito anos, provocou em mim um misto de maravilhamento e desânimo. Textos como "Investigações de um cão" e "A construção" representavam para mim ao mesmo tempo uma revelação da potência máxima da literatura e também um marco inatingível. Eu sabia que jamais poderia fazer nada semelhante ao que Kafka fizera, não apenas porque não era judeu nem falava alemão nem nascera no final do século XIX, mas também porque a espécie de dedicação que Kafka tinha pela literatura estava fora de meu alcance. Em algum lugar dos diários, numa passagem que não consigo mais localizar, Kafka escreve que nada na vida o interessa além da literatura, nada no mundo para ele tem o menor interesse, a menor importância, que não seja a literatura. Lendo e relendo

1. "Poesia: criação e tradução”. Ipotesi - Revista de Estudos Literários, (12)2, julhodezembro 2008, pp. 11-17. 
essa passagem com o fervor de um místico diante de um texto sagrado, eu me perguntava: serei capaz de afirmar o mesmo? E a sinceridade me obrigava a responder que não. Para mim, havia coisas mais importantes que a literatura - a música, certamente, para permanecer na esfera da arte, e muitas outras, numa perspectiva mais ampla. Decididamente, eu não era digno de ser escritor; e tampouco tinha talento musical. E, tendo desenvolvido uma consciência crítica razoável muito antes de ter dominado minimamente o artesanato verbal, eu percebia que minhas tentativas de escrever poesia, drama e prosa não passavam de tentativas malsucedidas. O que fazer?

A saída foi passar um ano e meio no estrangeiro estudando cinema. Embora eu terminasse por abandonar o curso ainda no início, tendo concluído que a ideia de me tornar cineasta era tão inviável quanto a de fazer carreira como músico, a temporada que passei na Califórnia estudando cinema foi um momento decisivo da minha formação, por vários motivos. Antes de mais nada, porque consolidou meu conhecimento do inglês, idioma que eu já havia aprendido na infância mas que, se não fosse por essa segunda estada num país anglófono, não teria se tornado para mim uma espécie de segunda língua materna, o que me qualificou para trabalhar como tradutor literário. Além disso, porém, meus dezoito meses na Califórnia me fizeram compreender pela primeira vez que era só através da literatura, da escrita, que eu poderia realizar alguma coisa que me proporcionasse algum grau de satisfação. A imersão na leitura dos grandes poetas do modernismo inglês - Eliot, Pound, Williams, mas sobretudo Stevens - me mostrou que, ao contrário do que eu havia concluído a partir do que lera nos ensaios e artigos dos irmãos Campos e do que eu ouvira nos debates sobre poesia de vanguarda realizados no MAM, não havia nada de vergonhoso ou retrógrado em estudar as formas poéticas tradicionais, em tentar dominar as seculares técnicas do verso, em português e inglês; não era preciso ser cancionista como Caetano Veloso ou Chico Buarque para utilizar sem culpa as formas do heptassílabo ou do decassílabo. Mas demorei algum tempo para voltar a escrever poesia em português; comecei escrevendo contos em inglês, contos que após voltar para o Brasil, passei algum traduzindo para o português e reescrevendo obsessivamente. Foi só mais tarde - creio que principalmente depois da traumática descoberta de "Uma faca só lâmina”, que tal como a leitura de Kafka, anos antes, por um momento me fez sentir que eu havia chegado tarde demais à literatura, depois que tudo que podia ser dito já tinha sido dito - foi só bem mais tarde que voltei a tentar escrever poesia em português. Por algum tempo, fiquei de 
certo modo bloqueado pela desconfiança em relação à minha capacidade de criar arte - ou, mais exatamente, em relação ao direito que eu teria de tentar ser escritor, não podendo fazer a profissão de fé extrema na literatura que eu lera nos diários de Kafka. Isso me levou, quando me inscrevi no Departamento de Letras da PUC-Rio, a optar não por literatura, e sim por linguística. Ao mesmo tempo que estudava gramática gerativa e semântica formal, eu me dedicava à tradução literária. Era como se, não me julgando capaz de escrever, nem com o direito de querer ser escritor, eu só me permitisse entrar no mundo das letras de modo indireto, como linguista, tradutor ou professor.

E no entanto voltei a escrever. Passado o impacto sufocante da primeira leitura de "Uma faca só lâmina", e empolgado com a tarefa de traduzir para o português alguns poemas de Stevens (sem que nenhuma editora tivesse me encomendado esse serviço), fui aos poucos voltando a escrever poesia, após um hiato de mais de seis anos. Um intervalo de seis anos hoje não me parece muito tempo, mas eu havia abandonado a poesia na adolescência, aos dezessete ou dezoito anos, e agora estava com mais de vinte e cinco. E mais uma vez dei por mim tentando utilizar os metros tradicionais e as formas clássicas. Esse minha atitude não era motivada, em absoluto, por um apego ao tradicionalismo, pelo repúdio à modernidade. Pelo contrário, os poetas que eu mais lia eram os modernistas, e a maior parte dos poemas que eu lia eram em versos livres. Não obstante, nesse período de retomada da poesia passei algum tempo escrevendo sonetos de modo quase compulsivo; cheguei a me despedir da forma algumas vezes, mas não demorava para que eu a retomasse. Sem dúvida, o uso de metros regulares era, em parte, uma compensação pela renúncia à música; escrever versos ritmados era uma maneira de fazer música com palavras. Mas minha formação literária sob o impacto das vanguardas do meio do século me fazia ver com certa desconfiança meu próprio apego à versificação. Foi só anos depois que encontrei uma solução intermediária, que até hoje adoto a maior parte do tempo: trabalhar com metros e formas tradicionais, escrever sonetos e decassílabos, porém alterando de algum modo essas formas, produzindo sonetos que não são bem sonetos, forjando decassílabos com ictos nas sílabas "erradas", explorando rimas incompletas e fazendo enjambements que turvam a fronteira entre os versos. Pouco depois de publicar meu primeiro livro, aos trinta e um anos, cheguei a ter a idéia de continuar a compor em versos, porém publicar os poemas como se fossem blocos de prosa, de modo a dificultar ao máximo a apreensão das formas métricas. Jamais cheguei a pôr em prática esse plano, mas o fato 
de eu tê-lo cogitado é revelador dos meus sentimentos ambivalentes em relação à poesia tradicional.

Percebo que, tendo escrito já algumas páginas sobre o que me levou e me leva a escrever, ainda não respondi a pergunta proposta. Deixando de lado a inevitável vaidade, e considerando que a vontade de expressão não é mais um dos principais fatores que me levam a escrever, por que é, afinal, que escrevo? E sou levado a dar duas respostas um tanto óbvias. Escrevo, em primeiro lugar, por força do hábito; porque desde tenra idade adquiri o costume de escrever; porque escrever faz parte da minha autoimagem; porque escrever é uma das coisas que me fazem sentir-me eu mesmo. Este motivo é certamente um dos mais importantes. Como já observei, a suposta autoexpressão da minha escrita adolescente revelouse, no final das contas, uma forma de autoconstrução: pois bem, o que construí através da escrita (e de outros meios, é claro) se caracteriza (entre outras coisas, é claro) pelo fato de que escrevo. Quando passo um período mais longo sem escrever, o que ocorre de vez em quando, sou dominado cada vez mais pela sensação de que estou em falta, em falta comigo mesmo; sinto, de algum modo, não estar cumprindo uma obrigação que, sei lá como nem por quê, impus a mim mesmo.

Mas escrevo, acima de tudo, creio eu, porque me dá prazer. Nunca consegui levar totalmente a sério os escritores que falam do sofrimento que é para eles escrever; sempre me pareceu haver em tais declarações um tanto de ingenuidade, ou de má-fé, ou das duas coisas misturadas. O próprio Kafka, que para mim permanece como um dos exemplos máximos de integridade artística, às vezes me parece sucumbir à idealização romântica da figura do artista como mártir, como vítima. Parece claro que, em última análise, escrever era para ele algo muito prazeroso, ao menos em certas ocasiões - do que, aliás, encontramos algumas comprovações nos seus diários e cartas, em meio a tanta reclamação e autocomiseração. Quanto a mim, a sensação que me domina quando encontro a palavra exata, quando resolvo de uma maneira aparentemente definitiva um problema de forma que me ocupou, de modo intermitente, por horas, dias ou mesmo anos - essa sensação é um prazer intenso, um prazer quase físico, muito embora, a esta altura da vida, eu saiba que, ao reler o poema no dia seguinte, as soluções que tanto me empolgaram na véspera vão parecer falhas e insatisfatórias.

No final das contas, pois, posso afirmar: escrevo acima de tudo por achar que escrever é fundamental para eu continuar me sentindo que sou quem sou, e por ser o ato de escrever uma fonte de intenso prazer. Essas duas motivações já bastam para que eu continue escrevendo. Se, 


$$
258 \text { - Remate de Males } 30.2
$$

além disso, vier algum reconhecimento, prestígio e até mesmo dinheiro, tanto melhor. Escrever é para mim uma atividade que se justifica por si só. O que vier a mais é lucro. 